\title{
A POLEWARD FLON ALONG THE ATLANTIC COAST OF THE IBERIAN PENINSULA
}

\author{
R. Haynes and E.D. Barton
}

Marine Science Laboratories, University College of North Wales Menai Bridge, Gwynedd, United Kingdom

\begin{abstract}
Satellite Advanced Very High Resolution Radiometer (AVHRR) imagery and Argos tracked drifters have revealed the existence of a narrow, warm surface poleward current along the Iberian coast during autumn and winter. Six near-surface drifter tracks indicated a net northward flow between September 1986 and March 1987, although individual drifter trajectories also provided evidence of eddy activity and episodes of equatorward flow. A Seasoar gurvey during September 1986 in the region $37^{\circ}-43^{\circ} \mathrm{N}$, $9^{\circ}-11^{\circ} \mathrm{W}$ showed that poleward flow at that time was associated with the northward advance of a warm, salty tongue of water throughout the upper $400 \mathrm{~m}$ layer. Infra-red imagery confirmed the northward penetration of the warm current and its progression around Cape Finisterre along the north coast of spain during the course of the winter. A similar situation is indicated by satellite imagery during other years. Current meter data show that poleward flow occurred along the continental slope down to depths greater than $600 \mathrm{~m}$. Conductivity, temperature, and depth (CTD) casts show the presence of Mediterranean Intermediate Water (MIW) at depths greater than $600 \mathrm{~m}$. The MIW does not flow as a simple northward flowing jet along the continental slope off Iberia, but instead shows evidence of eddies within the flow. The poleward surface current is in the opposite sense to the general sumer circulation of the region, when cool upwelled water is advected equatorward. It is postulated that the poleward flow is generated by thermohaline forcing when the southward trade winds, characteristic of the summer months, weaken or reverge. Intormittent poleward flow appears to be a common characteristic of the Eastern Boundary throughout the North Atlantic from West Africa to the Norwegian Sea.
\end{abstract}

\section{Introduction}

The continental shelf and slope waters off the Atlantic coast of the Iberian Peninsula are dominated throughout the summer months by strong coastal upwelling and associated equatorward surface flow in response to the 'Portuguese Trades' [Wooster et al., 1976; Fiuza, 1982], yet compared to other coastal upwelling regions very little investigation of the phenomenon has been carried out. The wintertime circulation is even less well known. No detailed field studies have been reported of the area since the work of Madelain [1967] and Lacombe [1971].

It is well established that Mediterranean Intermediate Water (MIw) flows northward along

Copyright 1990 by the American Geophysical Union.

Paper number $89 \mathrm{JC} 03637$.

0148-0227/90/98JC-03637\$05.00 the continental slope of the Atlantic coast of the Iberian Peninsula in a narrow (approximately $100 \mathrm{~km}$ ) vein, centered at a depth around $1000 \mathrm{~m}$ [Lacombe, 1971; Reid, 1979]. Some recent observations [Ambar, 1984; 1985] indicate that this poleward flow may extend from the bottom of the MIV $(1600 \mathrm{~m})$ to the top of the North Atlantic Central Water (NACW), i.e., the bottom of the surface mixed layer at $100-200 \mathrm{~m}$ depth. Such poleward flows bound to the continental slope are thought to be a common feature of sub-tropical eastern boundary regions [Wooster and Reid, 1963]. While there are numerous short term observations to show that similar flow can occur all along the eastern boundary of the sub-tropical gyre [Barton, 1989], few systematic or long term observations are available to define the meridional extent and continuity of the undercurrent. In other, similar areas, e.g., California [Huyer, 1983], it is found that during the upwelling season, when the trade winds dominate, the surface flow is equatorward over the shelf, but may become poleward at times of weak or northward wind. The seasonal variation of the surface flow off the Iberian coast is not well established.

In September to October 1986, a cruise was undertaken off the Iberian coast to investigate conditions over the continental margin. The resultant data set indicates that the season of upwelling had finished and that a regime of northward flow over the continental shelf and slope was being established. In this paper, we describe characteristics of the circulation based on shipboard, drifting buoy, and moored current meter observations. Satellite sea surface temperature imagery from a number of years (1982-1989) is used to show that the presence of a warm water mass extending along the Atlantic coast of Portugal around Cape Finisterre into the Bay of Biscay throughout the winter months (October-March) is a common occurrence.

\section{Data}

A mesoscale survey of waters over the continental shelf and upper slope off the Iberian Peningula was undertaken in September and october 1986 to study the spatial and temporal structure of the temperature, salinity, density, and velocity fields. The survey consisted of a Seasoar (undulating CTD) grid, down to a nominal depth of $325 \mathrm{~m}$ and three conventional CTD sections down to a depth of $1000 \mathrm{~m}$ (Figure 1). In addition, four current meter moorings were deployed over the continental slope and shelf, six satellite tracked mixed layer drifters were released, and continuous underway measurements of surface temperature and salinity were made.

The accuracy of the CTD temperatures was checked by the use of reversing thermometers. CTD salinities were checked againgt water bottle 


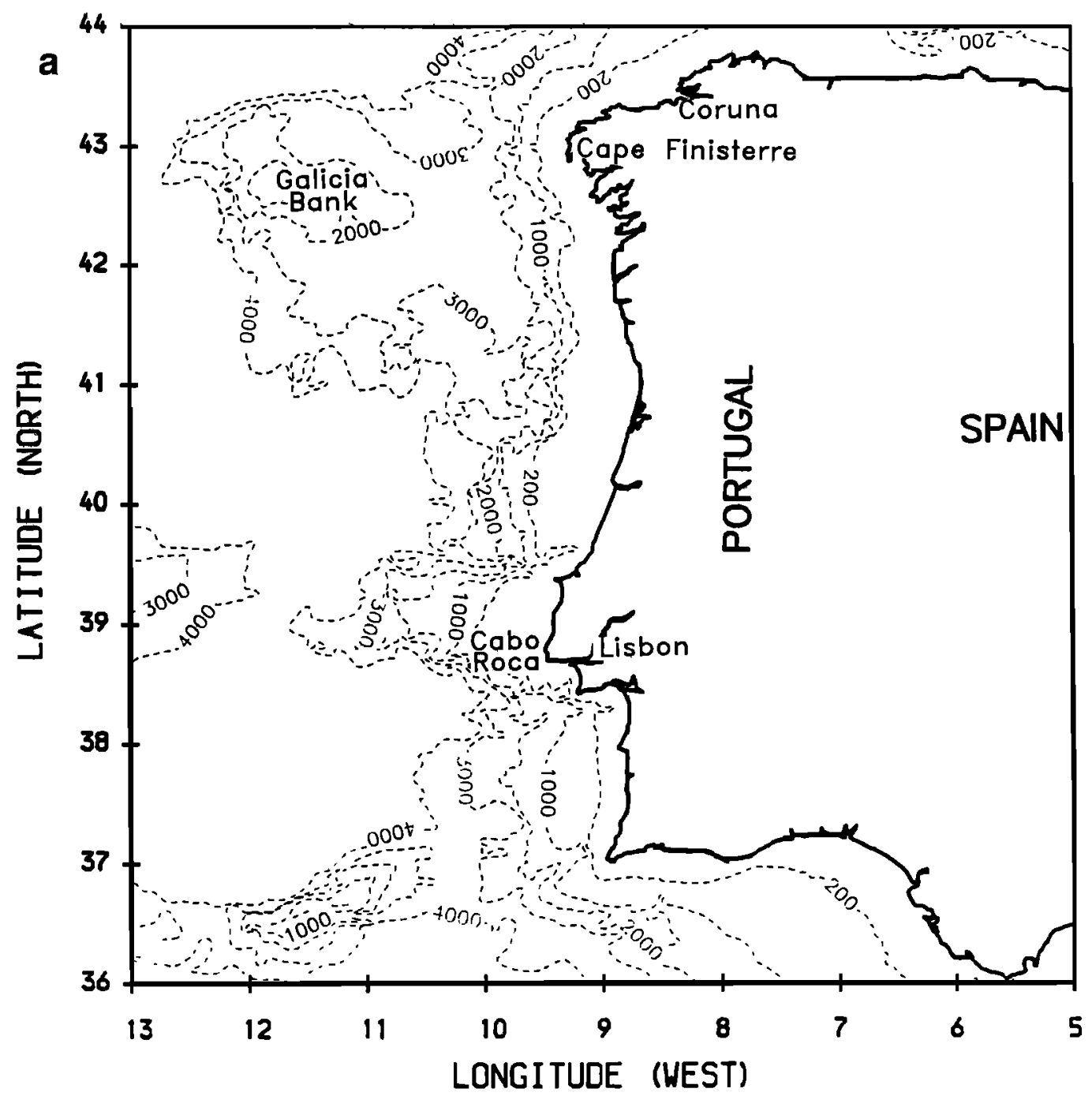

Fig. 1. (a) Bathymetry of the Atlantic Ocean west of the Iberian Peninsula. (b) The ship track for the period of the Seasoar survey (the ticks are at intervals of 1 hour, the Julian date is also indicated). The positions of the CTD stations are shown by squares and the mooring locations by asterisks.

sample salinities determined on an Autosal Guildline salinometer, which has a standard error of 0.003 practical salinity units (psu). The underway thermosalinograph temperature and salinity data were corrected by comparison with the surface values of the CTD.

During the period September 19-23 a survey was undertaken using an undulating CTD (SeaSoar) in the region $40^{\circ}-42^{\circ} \mathrm{N}, 9^{\circ}-11^{\circ} \mathrm{w}$. The survey consisted of a grid of north-south lines across a central east-west line (Figure 1). Data were obtained using a Neil Brown Mark III CTD mounted in the streamlined SeaSoar vehicle, which was towed using a faired cable at a speed of about 4 m $s^{-1}$. This enabled the instrument to cycle between 0 and $325 \mathrm{~m}$ depth, approximately every 10-12 minutes, which gives a horizontal resolution of about $2 \mathrm{~km}$. The data were processed to form a grid with a vertical spacing of $5 \mathrm{~m}$ and a horizontal spacing of about $2 \mathrm{~km}$. Current meter moorings were located at four sites (Figure 1) in the study area: three along the upper continental slope in $750 \mathrm{~m}$ (nominal current meter depths of $50,100,200,400$, and $600 \mathrm{~m}$ ) and one on the shelf in $100 \mathrm{~m}$ of water (nominal current meter depths of 30,60 , and $90 \mathrm{~m}$ ). Details are given in Table 1 . Observations were filtered and decimated to hourly values, then low-pass filtered and subsampled at 6-hour intervals.

At the beginning of the cruise between September 20-22, at the site and time of each mooring deployment, an Argos tracked near surface drifter was deployed. Two more were released further offshore. The buoys were tracked by the Argos system, and position fixes were obtained on average every 3-4 hours, although there were several periods when position updates were not obtained for 12 hours or more due to operating problems. The Argos system gives position fixes to an accuracy of $250 \mathrm{~m}$. These were tracked until they ceased to function, were washed ashore, or left the region of interest. The near-surface drifters were of the Tristar design and are believed to have excellent current following characteristics [Niiler et al., 1987]. Release positions and record lengths of the various 


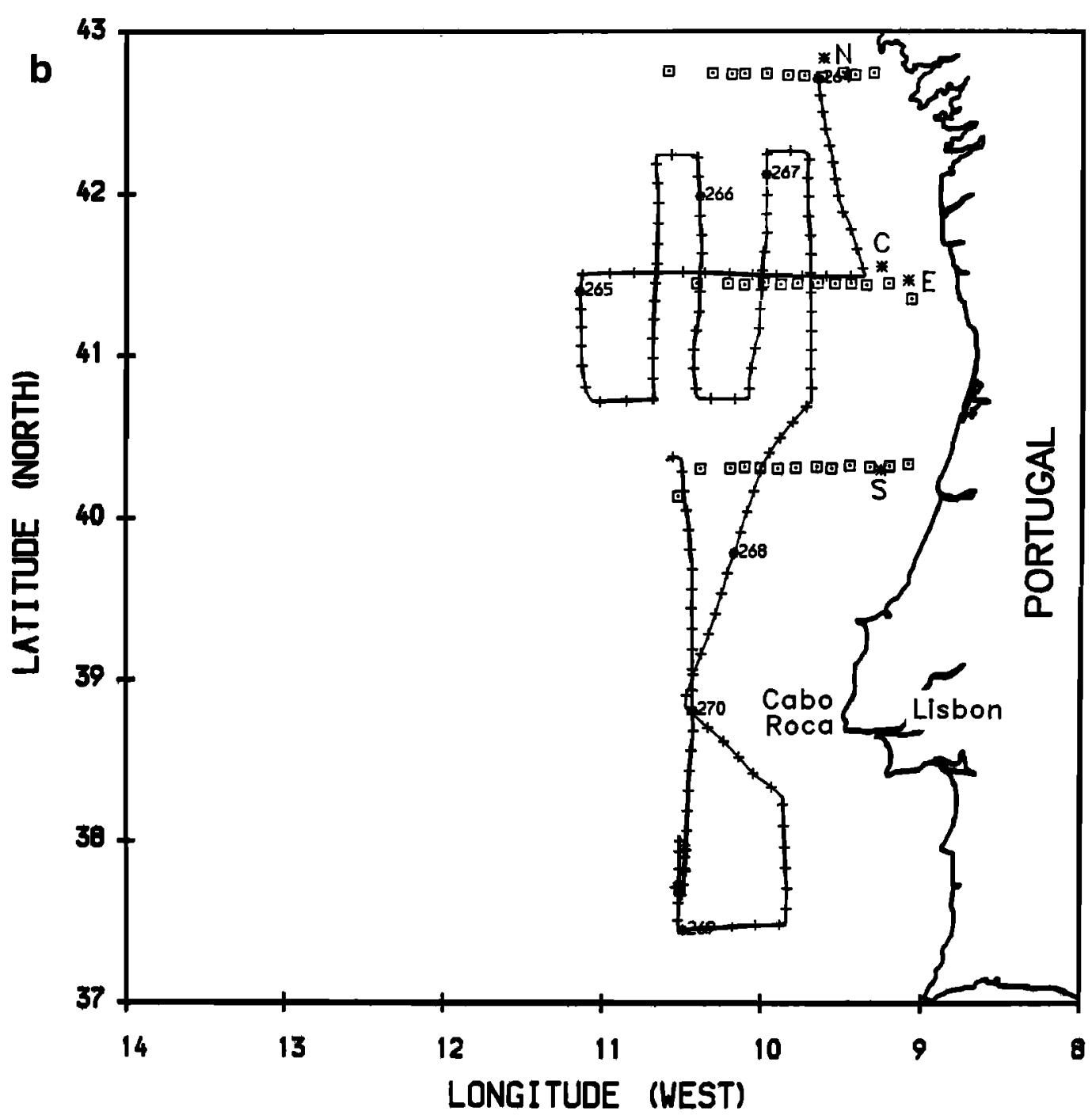

Fig. 1. (continued)

driftere are given in Table 2 . The data were interpolated to 1-hour intervals by use of a cubic spline, then filtered using a cosineLanczos fllter, with a half-power point at 40 houra, to remove tidal and inertial currents, and sub-sampled to six-hourly values.

sea surface temperature (SST) data from the advanced very high rosolution radiomoter (AVHRR) aboard the NOAA 9 satellite were obtained from the Oniversity of Dundee. The AVHRR is a scanning radiometer with five spectral bands, three of which are in the thermal infrared. The images were produced by using a linear weighted sum of

\begin{abstract}
11- and 12- $\mu \mathrm{m}$ infrared brightness temperature measurements (channels 4 and 5) of the $1 \mathrm{~km}$ resolution AVHRR data. The welghts used are those of McLain et al. [1985] which remove atmospherio water absorption effects to produce SST ostimates which may have an absolute accuracy as good as $1.0^{\circ} \mathrm{C}$ (ignoring skin effects such as diurnal heating of the top few decimeters). The estimates of horfzontal gradients of SST are much more accurate since the spatial scale of the atmospheric water vapor variability is large in relation to the gradients of SST [Chelton et al., 1988].
\end{abstract}

TABIE 1. Mooring Data

\begin{tabular}{lcccc}
\hline & \multicolumn{4}{c}{ Mooring } \\
\cline { 2 - 5 } & $\mathrm{N}$ & $\mathrm{C}$ & $\mathrm{S}$ & $\mathrm{F}$ \\
\hline Latitude, $\mathrm{N}$ & $42^{\circ} 49.4^{\prime}$ & $4^{\circ} 32.1^{\prime}$ & $40^{\circ} 17.5^{\prime}$ & $41^{\circ} 28.2^{\prime}$ \\
Longitude, & $9^{\circ} 38.1^{\prime}$ & $9^{\circ} 16.4^{\prime}$ & $9^{\circ} 16.4^{\prime}$ & $9^{\circ} 06.0^{\prime}$ \\
Depth (m) & 750 & 750 & 750 & 100 \\
Period (days) & 12 & 12 & 12 & 12 \\
\hline
\end{tabular}


TABLE 2. Iaunch Positions and Duration of the Drifters

\begin{tabular}{|c|c|c|c|c|c|c|c|}
\hline \multirow{2}{*}{$\begin{array}{l}\text { Drifter } \\
\text { Number }\end{array}$} & \multirow{2}{*}{$\begin{array}{l}\text { Latitude } \\
\text { (iN) }\end{array}$} & \multirow{2}{*}{$\begin{array}{l}\text { Longitude } \\
\text { ('พ) }\end{array}$} & \multirow{2}{*}{$\begin{array}{c}\text { Duration } \\
\text { (days) }\end{array}$} & \multicolumn{2}{|c|}{ u Component } & \multicolumn{2}{|c|}{$\checkmark$ Component } \\
\hline & & & & Mean & s.d. & Mean & s.d. \\
\hline 6220 & 41.4899 & $10 . \$ 320$ & 178 & -0.01 & 0.03 & 0.07 & 0.01 \\
\hline 6222 & 41.5133 & 10.0562 & 149 & 0.01 & 0.03 & 0.01 & 0.02 \\
\hline 6227 & 41.4833 & 9.3000 & 165 & -0.01 & 0.05 & -0.01 & 0.02 \\
\hline 6234 & 40.4533 & 9.8283 & 95 & -0.01 & 0.03 & 0.03 & 0.02 \\
\hline 6235 & 42.6952 & 9.6137 & 14 & 0.01 & 0.07 & -0.02 & 0.08 \\
\hline $6236 \star$ & 41.4917 & 9.1000 & 4 & 0.02 & 0.21 & 0.15 & 0.17 \\
\hline
\end{tabular}

Mean and standard deviation (s.d.) of onshore (u) and alongshore (v) components of current during the cruise period september 22 to October 2, 1986. Units are in meters per second.

* Duration of drifter was only 4 days

\section{Observations}

\subsection{Meteorological Conditions}

The surface circulation off the Iberian Peninsula is closely related to the large scale climatology of the northeast Atlantic. During the summer months when the Azores high pressure cell is located in the central Atlantic, and the Greenland low has diminished in intensity, the resulting pressure gradient forces air to flow southward along the coast of Iberia - a wind pattern that induces upwelling and an associated southward surface circulation. In contrast, in winter the Azores high pressure cell is located off the northwest African coast, and a deep low is located off the southeast coast of Greenland. The pressure gradient between the two pressure systems results in an onshore wind with a component of wind stress northward off rberia. This mean wind pattern is modified by the energetic winter 'lows' typical of the North Atlantic during the winter months.

The winds observed during the cruise period (Figure 2) at Lisbon $\left(38^{\circ} \mathrm{N}\right)$ and Coruna $\left(43^{\circ} \mathrm{N}\right)$ show that at the beginning of the cruise (September 17, Julian day 260) the winds were light and variable at Iisbon but were
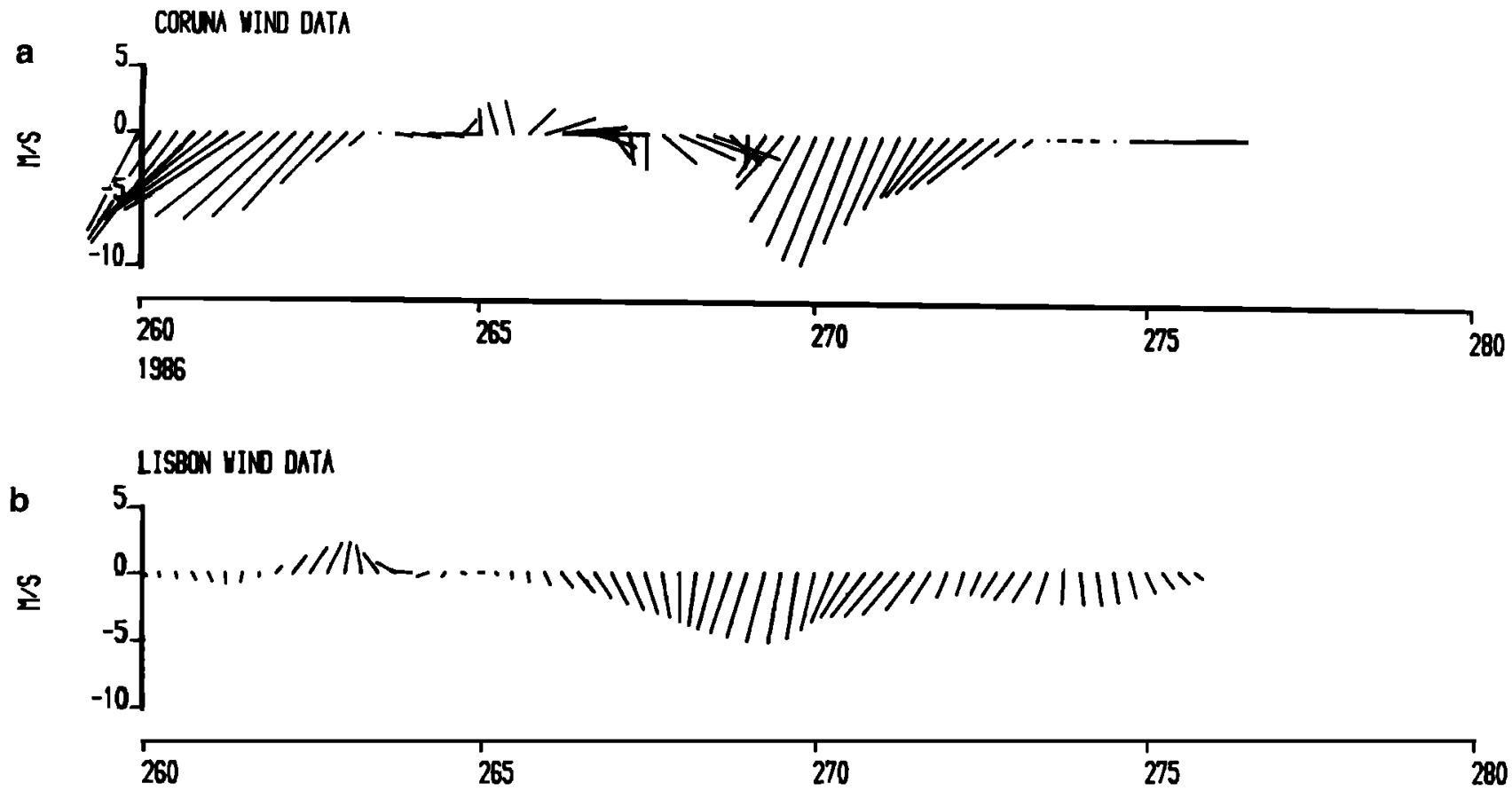

1986

Fig. 2. Vector plots of the winds at (a) Coruna $\left(43^{\circ} \mathrm{N}\right)$ and (b) Lisbon $\left(38^{\circ} \mathrm{N}\right)$. Sticks point toward the direction the wind was flowing, and the length of the sticks indicates the magnitude of the current (scale on left axis). 
predominantly southward (upwelling favorable) at Coruna, but by the September 22 (day 265) were at both sites weak and variable. The winds intensified so that by September 27 (day 270) they were moderate $\left(5-10 \mathrm{~m} \mathrm{~s}^{-1}\right)$ and upwelling favorable (southward). The winds stayed upwelling favorable to the end of the cruise (October 2) but diminished in intensity.

\subsection{Sea Surface Patterns}

Satellite SST data prior to the cruise period show that by the beginning of September 1986, any sign of significant cooling at the coast due to upwelling had disappeared. The infrared images abtained during the period of the cruise show the evolution of a warm sea surface temperature anomaly (Figures $3 a$ and $3 b$ ) seaward of the shelf break. These images are separated by over a week, and so small scale features will have little or no correlation between images, as the time scale exceeds that of the lifetime of most small eddies [Flament et al., 1985]. Near the start of the cruise the image on September 23 shows the presence of a warm water mass lying to the seavard of the shelf break (approximately along the $10^{\circ} \mathrm{W}$ meridian). The image shows that the warm oceanic waters oxtend in toward the coast, where only a weak cooling of the surface vaters is evident and the strong upwelling signature of the summer months is absent. The tongue of warm water appears to narrow northwards and may indicate some topographic funneling due to the pronounced ridge and rise of the Galicia Bank $\left(42^{\circ} 40^{\prime} \mathrm{N}\right.$, $11^{\circ} 30^{\prime}$ w). The other feature of note is a patch of cool upwelled water off Cabo Roca $\left(38^{\circ} 30^{\prime} \mathrm{N}\right)$.

\section{a SEA-SURFACE TEMPERATURE 23/09/86}

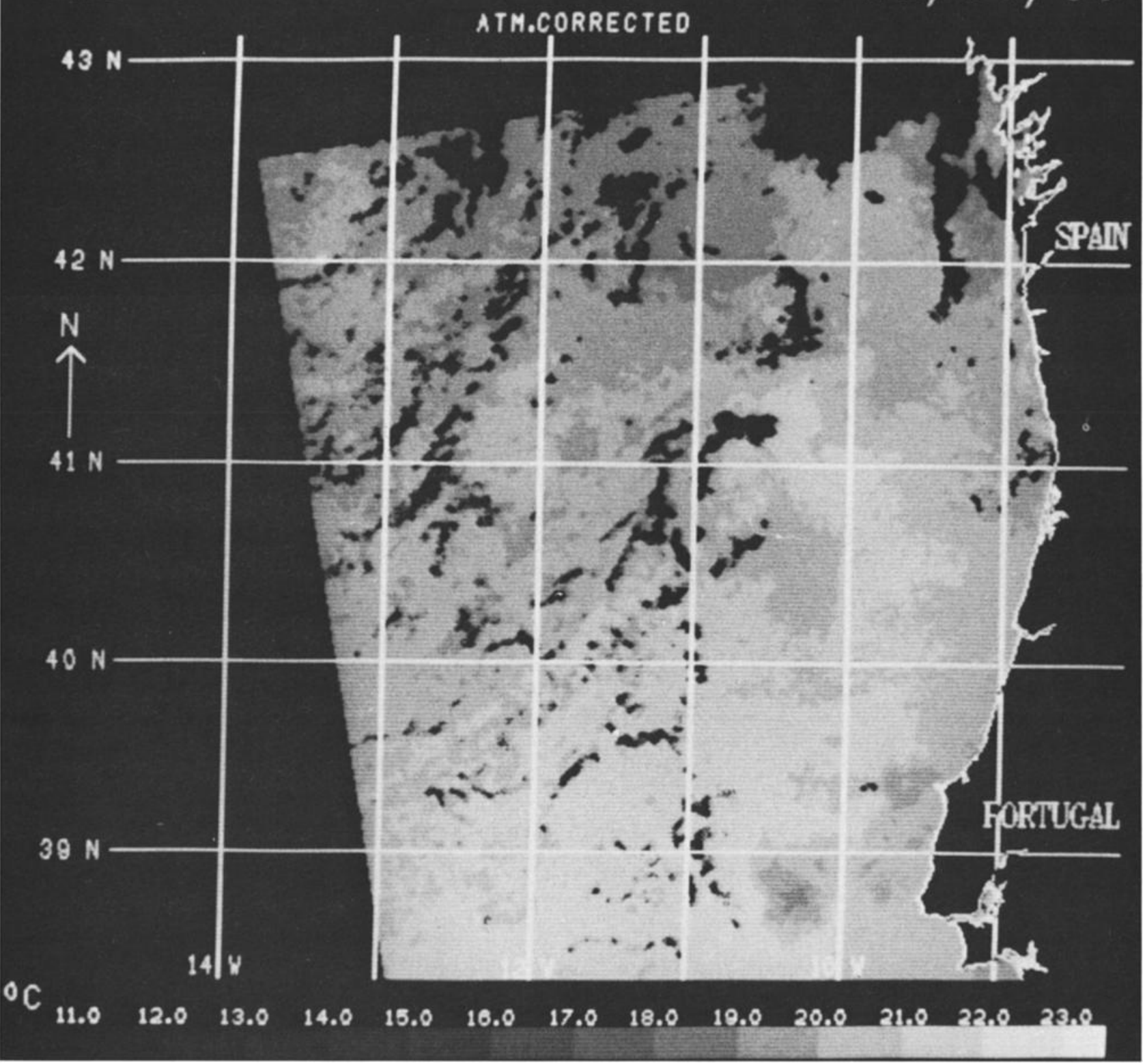

Fig. 3. AVHRR satellite images for (a) September 23, 1986 and (b) September 30, 1986, showing a warm temperature anomaly seaward of the continental shelf break. 


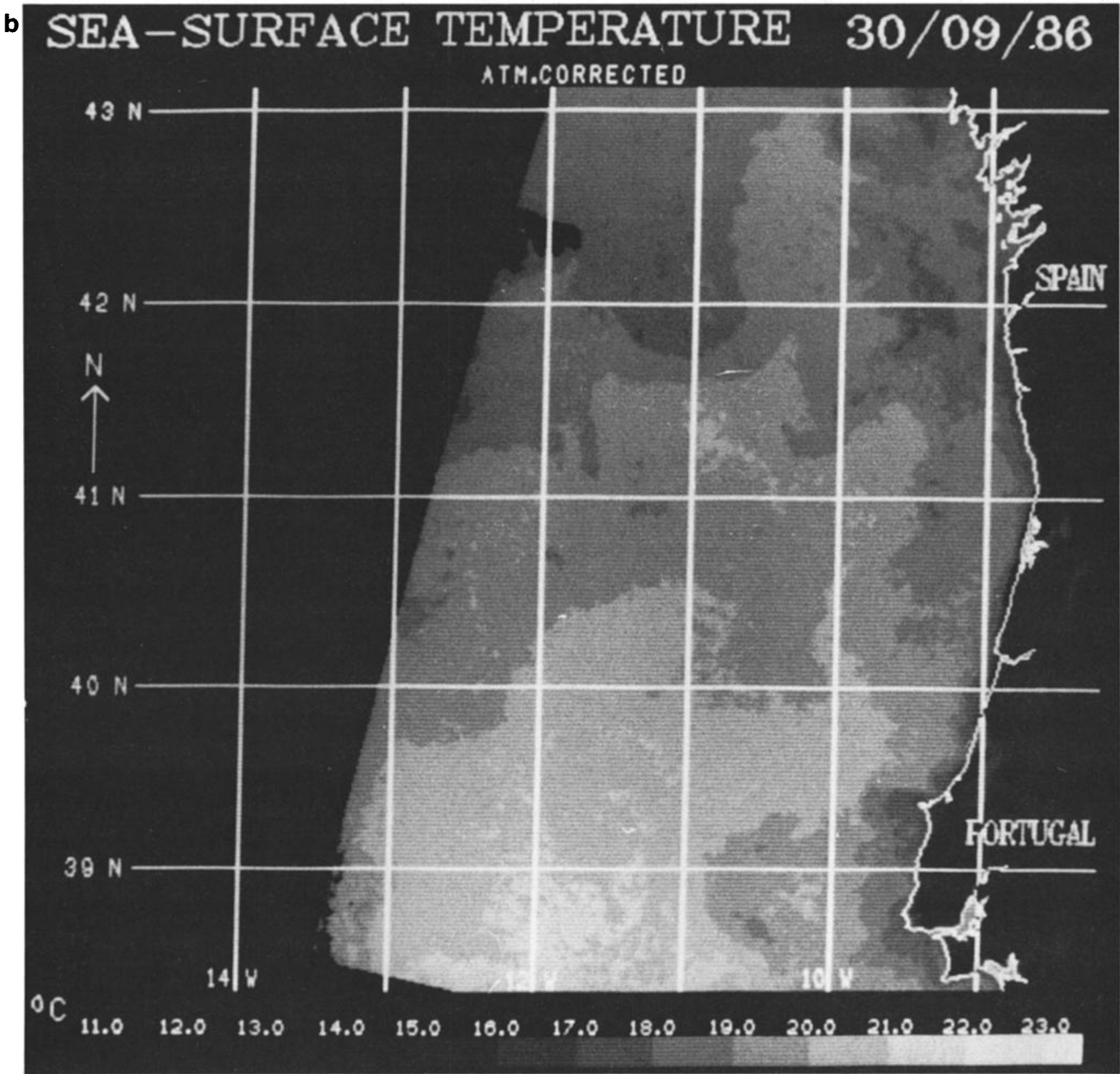

Fig. 3. (continued)

This is believed to be a remnant tongue of cool upwelled water detached from the coast when the upwelling favorable winds weakened.

The image obtained 7 days later on September 30 shows the persistence of the warm sea surface temperature anomaly lying seaward of the shelf break. This feature has a width of about 70-100 $\mathrm{km}$ and extends meridionally through the whole image. It is seen as a clearly visible tongue of warmer water meandering between $12^{\circ} \mathrm{W}$ on the southern edge of the image and $10^{\circ} 30^{\prime} \mathrm{W}$ in the north. The temperature in the middle of the tongue decreases by almost $3^{\circ} \mathrm{C}$ from south to north. The image also shows the temporary onset of upwelling off Cape Finisterre in response to the strengthening of equatorward, upwelling favorable winds during the middle of the cruise. The onset of this upwelling has important consequences for the evolution of the shelf currents, as over the shelf the currents reversed to flow equatorwards and the flow over the slope diminished in intensity.

The composite maps from the underway thermosalinograph data and the surface CTD data (Figure 4) exhibit close correspondence to the satellite SST images and show that the warm feature observed in the satellite images is associated with increased salinity. The most obvious feature to compare with the satellite imagery is the tongue of warm (greater than $19^{\circ} \mathrm{C}$ ) water observed at $42^{\circ} \mathrm{N}, 10^{\circ} \mathrm{W}$ which is associated with salinities greater than 35.60 psu. This increase in salinity is not, however, large enough to compensate for increase in temperature, and there is a resulting decrease in density of the waters in the warm tongue. 
TEMPERATURE

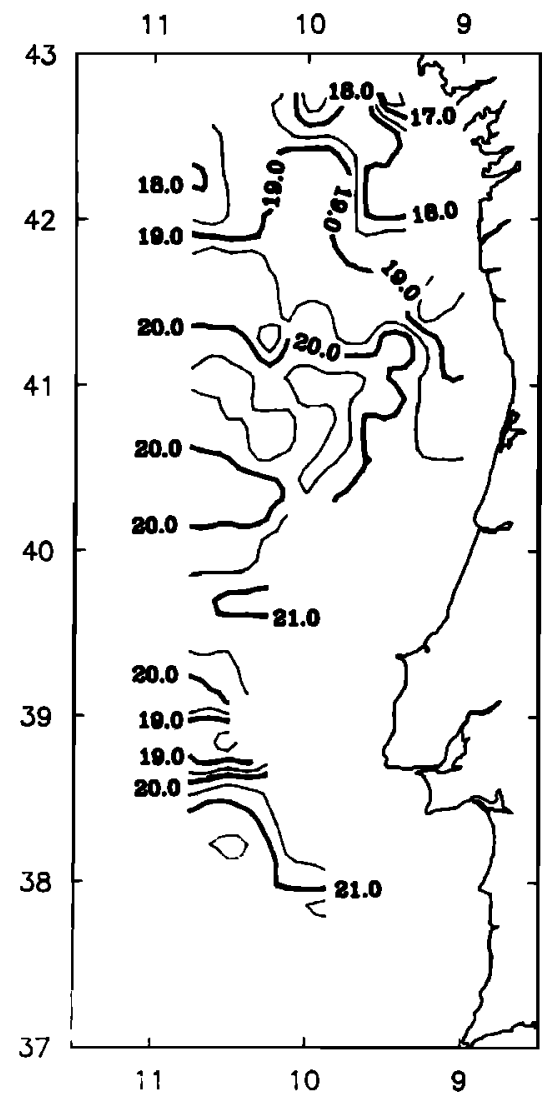

SALINITY

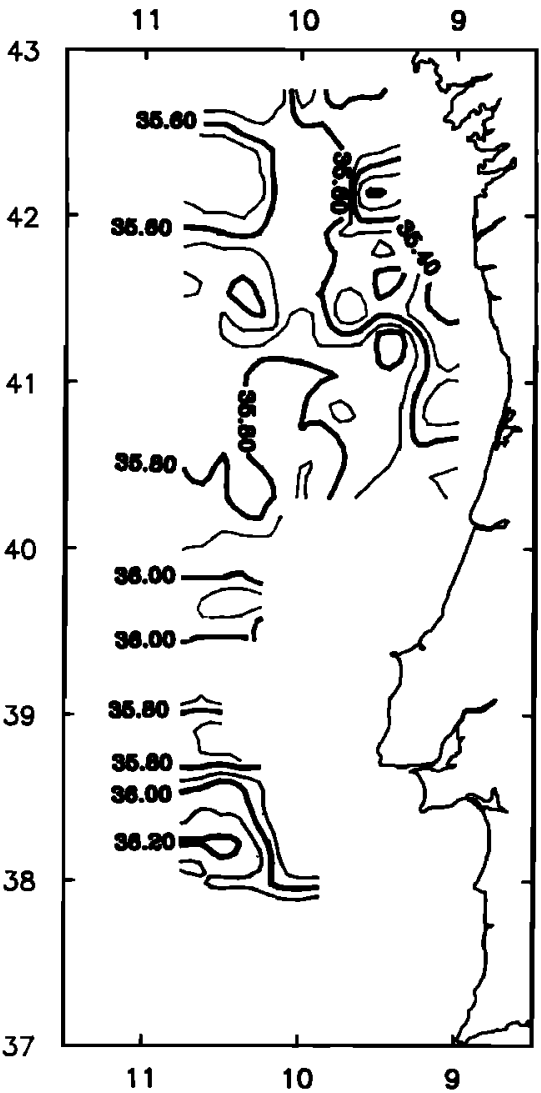

SIGMA-t

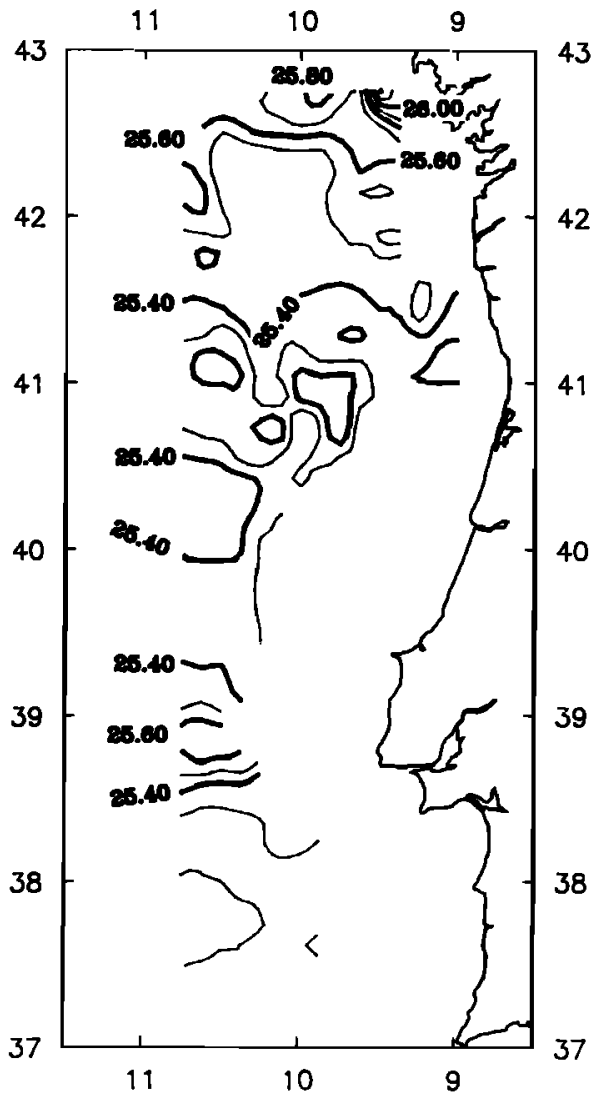

Fig. 4. Composite sea surface temperature, salinity, and density anomaly maps for the cruise, revealing the northward penetration of the warm, saline tongue.

The other features that were prominent in the satellite imagery are also seen in the surface data maps; the cold patch-like feature off Cabo Roca clearly identifiable on the image from September 23 is seen to be associated with relatively cold, fresh and dense water, although it is poorly defined because there were only two transects through the feature at almost the same location. Similarly, the region of coastal upwelling around Cape Finisterre $\left(43^{\circ} \mathrm{N}\right)$, visible on the image of september 30 is seen in the in situ sea surface temperature maps. The cold (less than $17^{\circ} \mathrm{C}$ ) upwelled water corresponds to density anomalies greater than $26.0 \mathrm{~kg} \mathrm{~m}^{-3}$. The cold, dense water resulted from the resurgence of weak upwelling which correlated with the re-establishment of weak upwelling favorable winds, measured at both Ia coruna $\left(43^{\circ} \mathrm{N}\right)$ and Lisbon $\left(39^{\circ} \mathrm{N}\right)$. The salinity field shows the influence of coastal runoff from the Rias of Galica, as at $42^{\circ} \mathrm{N}$ there is a marked salinity minimum with salinities less than 35.30 psu being observed.

\subsection{SeaSoar Survey of Mooring Area}

The combination of zonal section along the line of the central moorings and meridional sections in the initial survey grid (which consisted of one central zonal line and five meridional lines worked from west to east, i.e. toward the coast) showed that the warm, salty anomaly was being advected polewards through the region. The initial zonal section of september 21 (Figure 5a) showed no water of salinity greater than 35.65 psu, but as the grid was traversed north and south, it was evident that higher salinities were being found further to the north on each traverse. The first north-south line, on September 22 (Figure $5 b$ ), shows water with a salinity of 35.70 psu just having reached the position of the zonal line. By the time of the final meridional line (September 24), water of salinity greater than 35.75 psu had reached a position well to the north of the original zonal line. Thus the higher salinity water had been advected at least $70 \mathrm{~km}$ over the 3 days necessary to run the grid, corresponding to a mean northward drift of $0.27 \mathrm{~m} \mathrm{~s}^{-1}$. The highest salinity was found in a maximum centered at about $80 \mathrm{~m}$ depth, but, in fact, salinity over the whole upper $300 \mathrm{~m}$ sampled had increased by about 0.1 pou during the survey.

\subsection{Current Meter Observations}

The mean currents (Figure 6) indicated that northward flow was present at nearly all depths sampled $(50 \mathrm{~m}$ to $600 \mathrm{~m}$ ). At mooring $\mathrm{S}$ flow was poleward at all depths, with the maximum at 600 $\mathrm{m}_{\mathrm{f}_{1}}$ where the mean current speed was nearly $0.20 \mathrm{~m}$ $s^{-1}$. At the central slope mooring (C) the maximum poleward flow was observed at $200 \mathrm{~m}$, and was again of the order of $0.20 \mathrm{~m} \mathrm{~s}^{-1}$. At $600 \mathrm{~m}$ the 

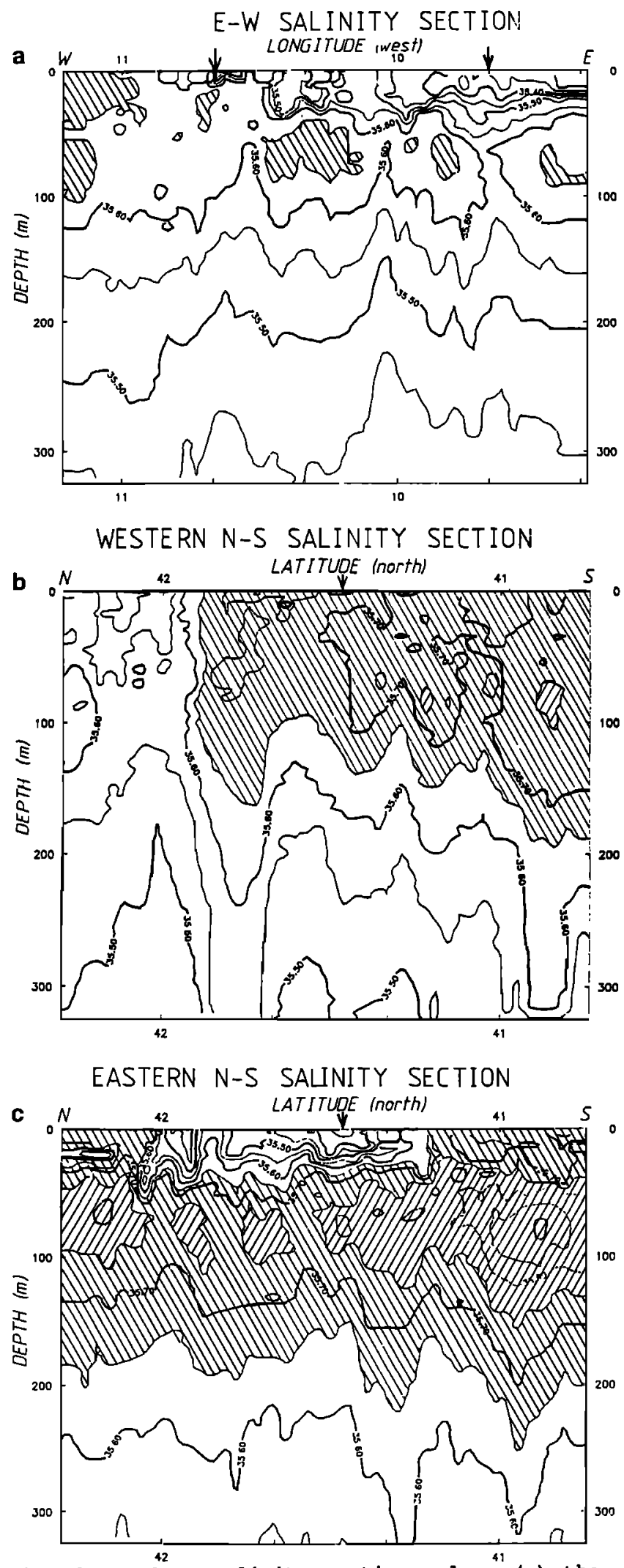

Fig. 5. Seasoar salinity sections along (a) the zonal line (September 21), (b) the offshore meridional line (September 22), and (c) the meridional nearshore line (September 24) showing the advection of the salinity maximum northwards as the ship progressed around the grid. Arrows indicate the crossing points of the lines. mean flow was poleward, but was much reduced in magnitude $\left(0.05 \mathrm{~m} \mathrm{~s}^{-1}\right)$. This reflects the return to weak equatorward flow at the end of the cruise. The currents at $50 \mathrm{~m}$ exhibited the same behavior. The alongshore $(v)$ component of the current at all depths was significantly correlated with the equatorward winds at Lisbon (Table 3). A similar set of observations result from the northernmost slope mooring (N), where the maximum mean poleward flow was seen at $100 \mathrm{~m}$. The currents at depths of $600 \mathrm{~m}$ and $50 \mathrm{~m}$ actually had an equatorward mean. The near-surface $(50 \mathrm{~m})$ flow was related to the onset of upwelling observed in the infrared images. The currents at the shelf mooring can be directly attributed to wind forcing (Table 3 ). The currents responded rapidly at all depths to the applied alongshore wind stress. The depth of the maximum poleward slope currents decreased from $600 \mathrm{~m}$ at the southern slope mooring to around $100 \mathrm{~m}$ at the northern mooring.

A vector time series plot of the currents at mooring $C$ shows a significant weakening of northward flow during the cruise (Figure 7 ). This is correlated with the re-establishment of the weak upwelling favorable winds and coincided with the temporary re-appearance of cool coastal water in the imagery. The degree of correlation between the alongshore currents and the wind is generally significant at the 97.58 lovel even at depths of $600 \mathrm{~m}$. It can be concluded from our observations that the weaker the equatorward wind stress, the stronger the poleward flow observed. If the equatorward wind stress is strong enough, the poleward flow can be seen to reverse.

\subsection{Drifter Tracks}

The mixed layer drifters drogued at $5 \mathrm{~m}$ mostly moved northwards during the cruise period (Table 2). The tracks during the cruise period superimposed on a satellite image show good correspondence with temperature features (Figure 8). The northward motion was not uniform through the area, but appeared strongest (up to $0.25 \mathrm{~m}$ $s^{-1}$, in the warm tongues at the nearshore and offshore ends of the mooring line. The northernmost drifter (6235) traveled northeastward around Cape Finisterre before almost retracing its trajectory to the southwest in association with the episode of equatorward wind around September 27 and the reversal of the currents at the moorings. In the center of the region there is some evidence of convergent equatorward flow, probably related to the current reversal to equatorward flow over the shelf, as buoys 6227 and 6222 are seen to converge and move southward around September 27 (day 270). This region of convergent flow can be seen on the satellite image (Figure 8 ) as a tongue of cold upwelled water extending southwards from the upwelling center near Cape Finisterre into a meander of the northward flowing warm water.

Surface layer drifters tracked until March 1987 demonstrated a net poleward flow during autumn and winter. Although the mean flow is poleward, the current field off Iberia is complicated by many mesoscale eddies, and intense poleward flow tends to occur sporadically. The paths of two of the buoys (6220 and 6222) were similar. The drifters flowed northwards during the cruise period before becoming entrained in a 


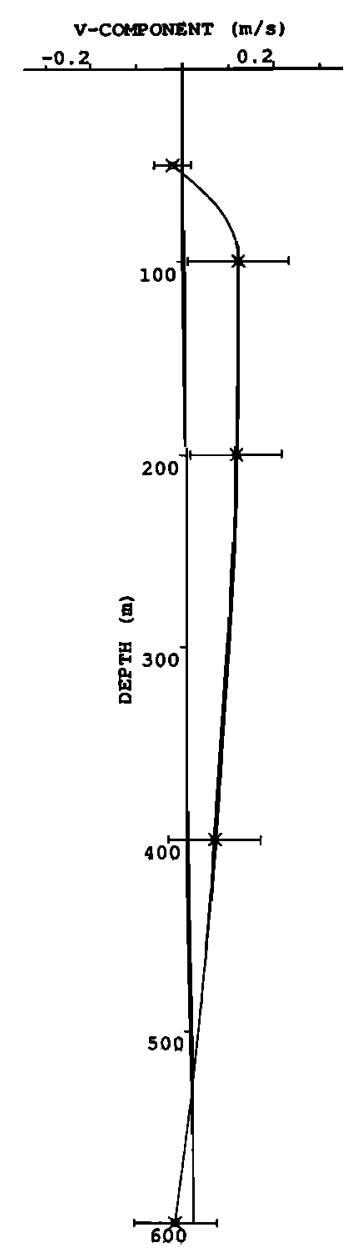

MOORING N

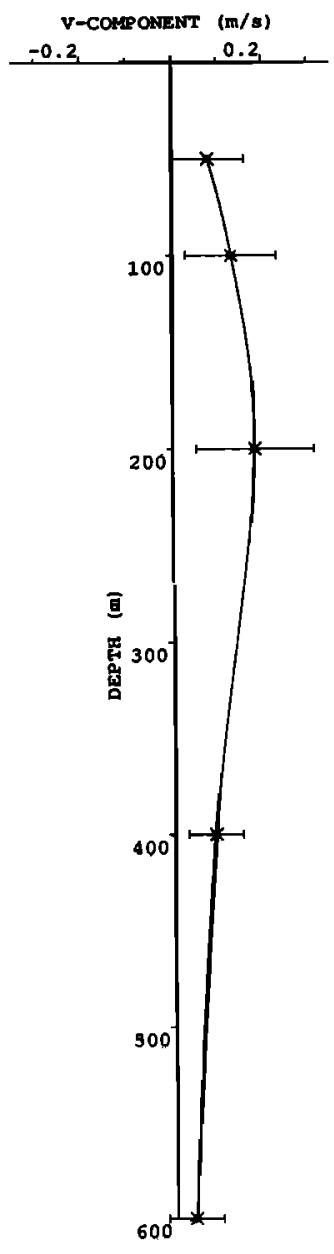

MOORING C

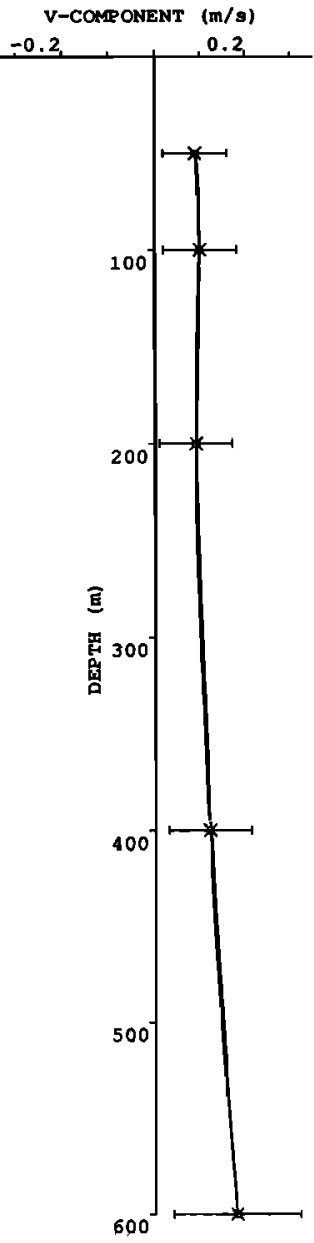

MOORING S
$\mathrm{V}$-COMPONENT $(\mathrm{m} / \mathrm{s})$

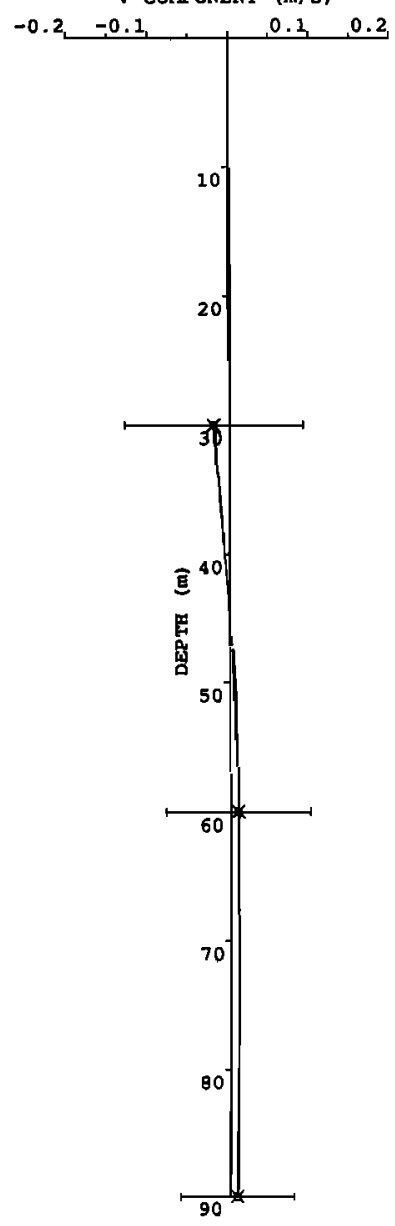

MOORING E

Fig. 6. The mean and standard deviation of the northward component of current observed at each of the mooring sites.

cyclonic eddy southeast of the Galica Bank $\left(42^{\circ} 40^{\prime} \mathrm{w}, 11^{\circ} 30^{\prime} \mathrm{w}\right)$ for a period of about a month. At the beginning of December 1986 both drifters became entrained in a northward flowing current of $0.25 \mathrm{~m} \mathrm{~m}^{-1}$. Drifter 6220 followed almost exactly the same track as 6222 but was approximately 10 days behind. Around the middle of December (day 354) the two tracks separated as the leading drifter (6222) moved around Cape Finiaterre and along the north coast of spain into the Bay of Biscay (Figure 9a). Drifter 6220 diverged from this track at Cape rinisterre ( $43^{\circ} \mathrm{iN}$ ) to travel northwards across the mouth of the Bay of Biscay. Drifter 6222 followed a path which corresponds closely to a warm water tongue seen in AVHRR imagery from different year's along the Biscay coast of Spain (Figure 9b), although in the winter of 1986-1987 the scene was obscured by persistent cloud. In this satellite image from January 1988, cold, fresh outflow from several of the Galician Rias can be seen turning northward along the coast as they become incorporated into the flow. The flow is about $50 \mathrm{~km}$ wide, has an average temperature of $2^{\circ}-3^{\circ} \mathrm{C}$ higher than the surrounding coastal and oceanic waters, and lies seaward of the shelf break.
An examination of all the cloud free AVHRR images from 1982-1989 shows the freguent presence of arm water mass seaward of the shelf break, along the north and west coasto of Iberia, during the winter montho (October-March). The warm water anomaly is of the order of $50 \mathrm{~km}$ in width and usually extends as far east into the Bay of Biscay as $6^{\circ} \mathrm{w}$. In ome images, however, this flow can be observed to reach as far east as the French border. The feature is normally trapped to the continental slope, but in the region $41^{\circ}-43^{\circ}$ $N$ there is frequently evidence of meandering of the flow away from the shelf break as in Figures $3 a$ and $3 b$.

\section{3,6. CTD Observations}

The results from the southern line $\mathbf{s}$ show that the surface temperature (Figure 10a) is rather uniform, but a slight gradient is seen from $18^{\circ}-19^{\circ} \mathrm{C}$ over the continental shelf to $19^{\circ}-20^{\circ} \mathrm{C}$, seaward of the shelf break. The temperature of the deeper waters shows the influence of the Mediterranean outflow as a temperature increase at depths greater than $500 \mathrm{~m}$. The outflow is seen to form two distinct cores, both centered at 
TABLE 3. Mean and standard Deviation of Onshore (u) and Alongshore

(v) Components of Curfent at Mooring sites and Corfelations Between Alongshore $(\nabla)$ Component and Alongshore Component of wind at Iisbon

\begin{tabular}{|c|c|c|c|c|c|c|c|}
\hline \multirow[t]{2}{*}{ Depth (m) } & \multicolumn{2}{|c|}{ u Component } & \multicolumn{2}{|c|}{$\checkmark$ Component } & \multirow{2}{*}{$c_{0}$} & \multirow{2}{*}{$c_{M}$} & \multirow{2}{*}{$\begin{array}{c}\mathrm{L}_{M} \\
\text { (hours) }\end{array}$} \\
\hline & Mean & s.d. & Mean & s.d. & & & \\
\hline \multicolumn{8}{|c|}{ Mooring $N$} \\
\hline 50 & -0.01 & 0.04 & -0.02 & 0.04 & 0.205 & & \\
\hline 100 & -0.03 & 0.02 & 0.12 & 0.11 & $0.911 *$ & $0.911 *$ & 0 \\
\hline 200 & -0.02 & 0.01 & 0.11 & 0.10 & $0.901 *$ & $0.919 *$ & -6 \\
\hline 400 & 0.00 & 0.01 & 0.06 & 0.10 & 0.801 & 0.842 & -12 \\
\hline 600 & 0.00 & 0.02 & -0.04 & 0.09 & $0.897 *$ & $0.897 \star$ & 0 \\
\hline \multicolumn{8}{|c|}{ Mooring C } \\
\hline 50 & 0.01 & 0.03 & 0.08 & 0.08 & 0.561 & $0.736 *$ & -18 \\
\hline 100 & -0.01 & 0.01 & 0.13 & 0.10 & 0.661 & $0.740 *$ & -12 \\
\hline 200 & 0.00 & 0.02 & 0.18 & 0.13 & 0.571 & 0.654 & -12 \\
\hline 400 & -0.01 & 0.01 & 0.09 & 0.06 & 0.455 & & \\
\hline 600 & 0.00 & 0.01 & 0.04 & 0,06 & 0.770 & $0.824 *$ & -12 \\
\hline \multicolumn{8}{|c|}{ Mooring $\$$} \\
\hline 50 & 0.02 & 0.04 & 0.09 & 0.07 & -0.048 & $0.556 *$ & -30 \\
\hline 100 & 0.00 & 0.03 & 0.10 & 0.08 & 0.141 & & \\
\hline 200 & 0.01 & 0.04 & 0.09 & 0.08 & 0.039 & & \\
\hline 400 & 0.00 & 0.02 & 0.12 & 0.09 & 0.754 & & \\
\hline 600 & 0.03 & 0.04 & 0.18 & 0.14 & 0.162 & & \\
\hline \multicolumn{8}{|c|}{ Mooring E } \\
\hline 30 & -0.01 & 0.02 & $-0,02$ & 0.11 & $0.918 *$ & $0.918 *$ & 0 \\
\hline 60 & -0.04 & 0.03 & 0.01 & 0.09 & 0.964 * & $0.964 *$ & 0 \\
\hline 90 & -0.03 & 0.03 & 0.01 & 0.07 & $0.933 *$ & 0.933 * & 0 \\
\hline
\end{tabular}

Correlation at zero lag denoted by $C_{0}$, maximum correlation by $C$ and the lag at maximum correlation by $L_{M}$. Positive lags indicate currents lead wind. Units are in meters per second.

*Correlations significant at the $97.5 \%$ level.

about $800 \mathrm{~m}$. One of these hugs the continental slope, while the other is detached at the offshore end of the section. The salinity section (Figure 10b) shows the same near-surface core of high salinity (>35.75 psu) as observed on the SeaSoar sections. The salinity maximum is seen to reach the sea surface seaward of the shelf break. The salinity section also shows the splitting of the warm, high salinity Mediterranean water into two cores. In the density section (Figure 10c) the isopycnals slope downwards to the middle near $10^{\circ} 20^{\prime} \mathrm{W}$ due to the splitting of the MIW flow into two cores.

Along the northern line $N$, the surface temperature (Figure 11a) shows a decreage from $18^{\circ}-19^{\circ} \mathrm{C}$ offshore to $15^{\circ}-16^{\circ} \mathrm{C}$ inshore over the continental shelf. This oan be attributed to the uptrelling off Cape Finisterre which has been observed in all the other data sots. The surface salinity section (rigure 11b) shows, like line $C$, the nearshore low salinity coastal runoff; the near-surface high salinity ( $>35.75$ pgu) core is much weaker in this line than the other two and is beginning to separate into a number of small intrusions. The density section (Figure 11c) shows weak surface gradients associated with the upwelling. The doep water shows features very like line $s, 1 . e$. the Mediterkanean pater is split into two cores at about $800 \mathrm{~m}$.

The rather uniform surface temperature of the central line C (Figure 12a) confirms the absence of active upwelling along this section. The near-surface salinity (Figure 12b) again shows a high salinity core offohore of the continental slope. A surface salinity minimum soen at the surface at the east of the section probably indicates coastal runoff. The temperature and salinity structure of the deep Mediterranean outflow is significantly different from that seen in lines $N$ and $s$. It is much more uniforth with only one small pertubation detached from the coast. The near-surface density field (Figure 

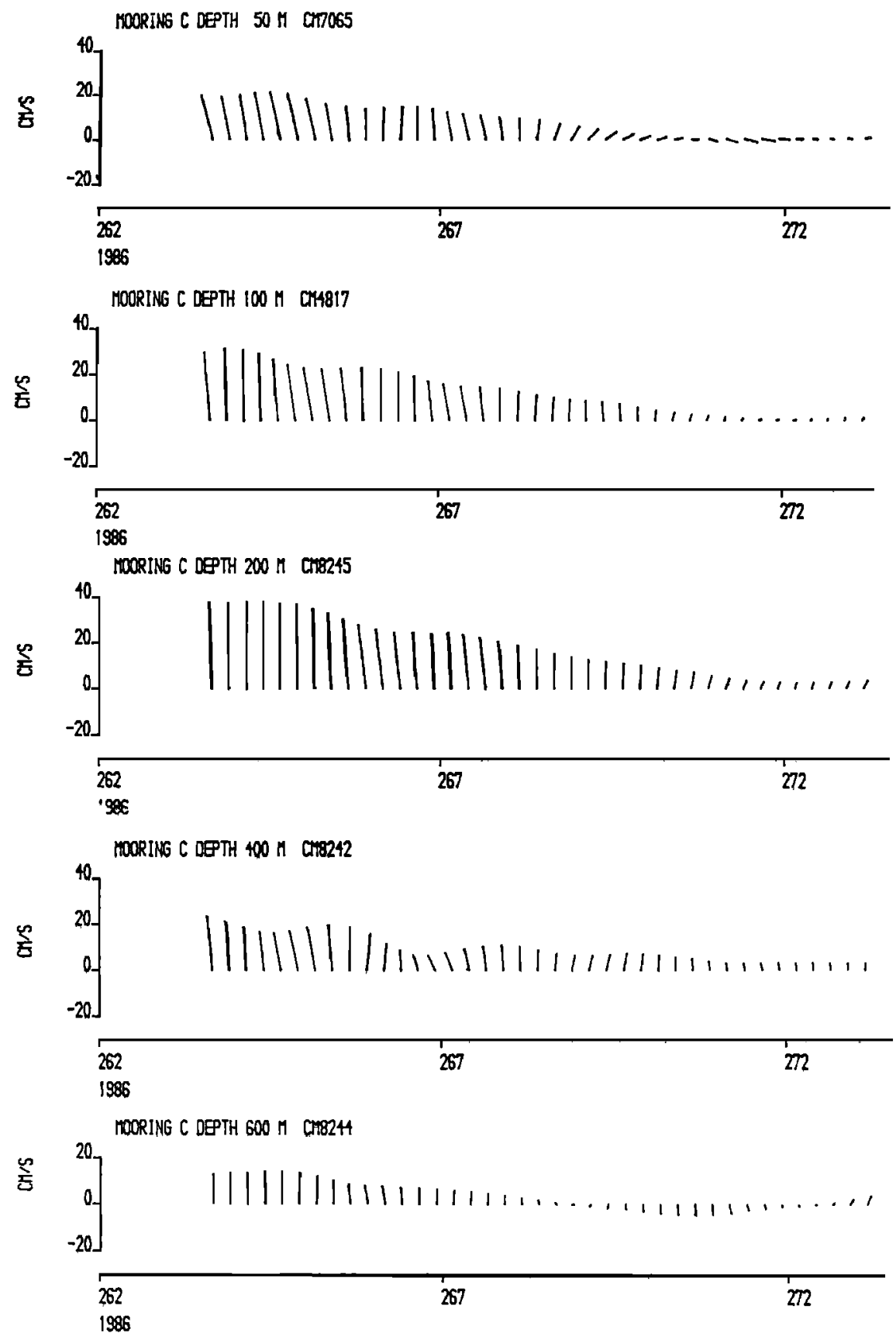

Fig. 7. Stick plot of low-pass-filtered vector currents from the central slope mooring (C). Sticks point toward the direction the current was flowing, and the length of the stioks indicates the magnitude of the current (scale on left axis).

12c) is uniform, but the deeper field illustrates the difference in structure from lines $N$ and $s$, as the isopycnals instead of sloping down to a low at $10^{\circ} 20^{\prime} \mathrm{W}$ slope up to a high. The difference between the Mediterranean outflow at the central CTD line and the other two would seem to indicate deep eddy recirculation.

The near-surface salinity maximum observed at all the lines is seen to weaken as it is advected northwards. This is due to lateral and vertical mixing with the surrounding North Atlantic Central Water (NACW).

\section{Discussion}

The evidence from the cruise shows that there was otrong poleward flow on the Iberian continental shelf and slope during september 1986. The flow was associated with the northward advection of anomalously warm and salty water with water mass characteristics similar to waters ftom the Gulf of Cadiz. Satellite IR imagery from 1982 to 1988 shows that the poleward advection of a warm water mass along the continental slope is a pergistent feature of the winter (October- 


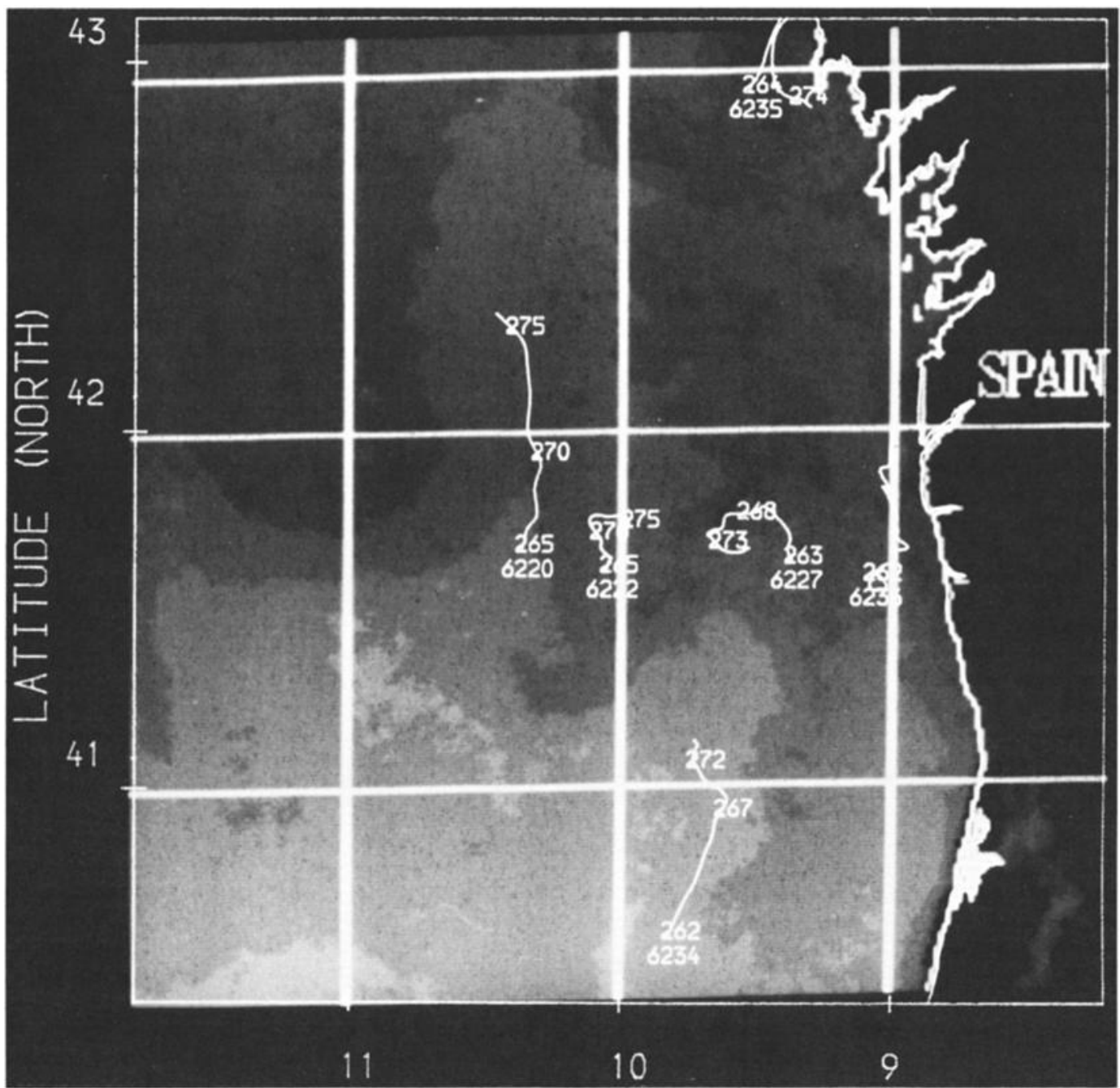

Fig. 8. AVhRR infrared sea surface temperature image for september 30, 1986, showing the intrusion of the warm water anomaly along the continental slope. Superimposed are 10-day trajectories for the six mixed layer drifters deployed at the start of the cruise.

March) circulation off the Iberian Peninsula. rigure $9 b$ shows one such example from the winter of 1987-1988 where a warm water mass is clearly seen to extend around Cape Finisterre into the Bay of Biscay.

A similar nearshore poleward flow has been observed off Iberia during the winter of 1983 by Ambar ot al. [1986]. They postulated that the driving mechanism for this phenomenon was northward wind stress associated with an anomalous southward displacement of the Azores high pressure cell. This northward wind stress causes an onshore Ekman transport which induces downwelling at the coast and a corresponding northward geostrophic current. McClain et al. [1986] concluded that a northward flow observed near the shelf break off Galicia, Spain, during April 1982 was the result of a negative wind stress curl in the immediate vicinity of the coast. The existence of the negative wind stress curl was believed to be due to the adjacent coastal morphology, where steep-sided rias channel the wind towards the southwest. However, the presence of a poleward flow to the south of
Galicia where the coastal morphology cannot produce this orographic effect would indicate that another driving mechanism is responsible.

There are a number of other subtropical eastern boundary regions where poleward flows are observed for at least part of the year. The most studied region is the west coast of the United States, where regular hydrographic studies have been carried out for the past 30 years (CalcorI). Iynn and simpson [1987] showed that in the California Current system there was a tendency for flow to be poleward at some level year round. This subsurface flow, referred to as the California Undercurrent (CU), has a high velocity core located along the continental slope. A poleward surface flow confined primarlly over the continental slope and shelf off California is observed from October to February. This is known as the Davidson current or the Inshore countercurrent. The evidence presented by Lynn and Simpson [1987] suggests that the autumn-winter appearance of the Davidson Current is associated with the shoaling of the California Undercurrent. McCreary et al. [1987], who studied 


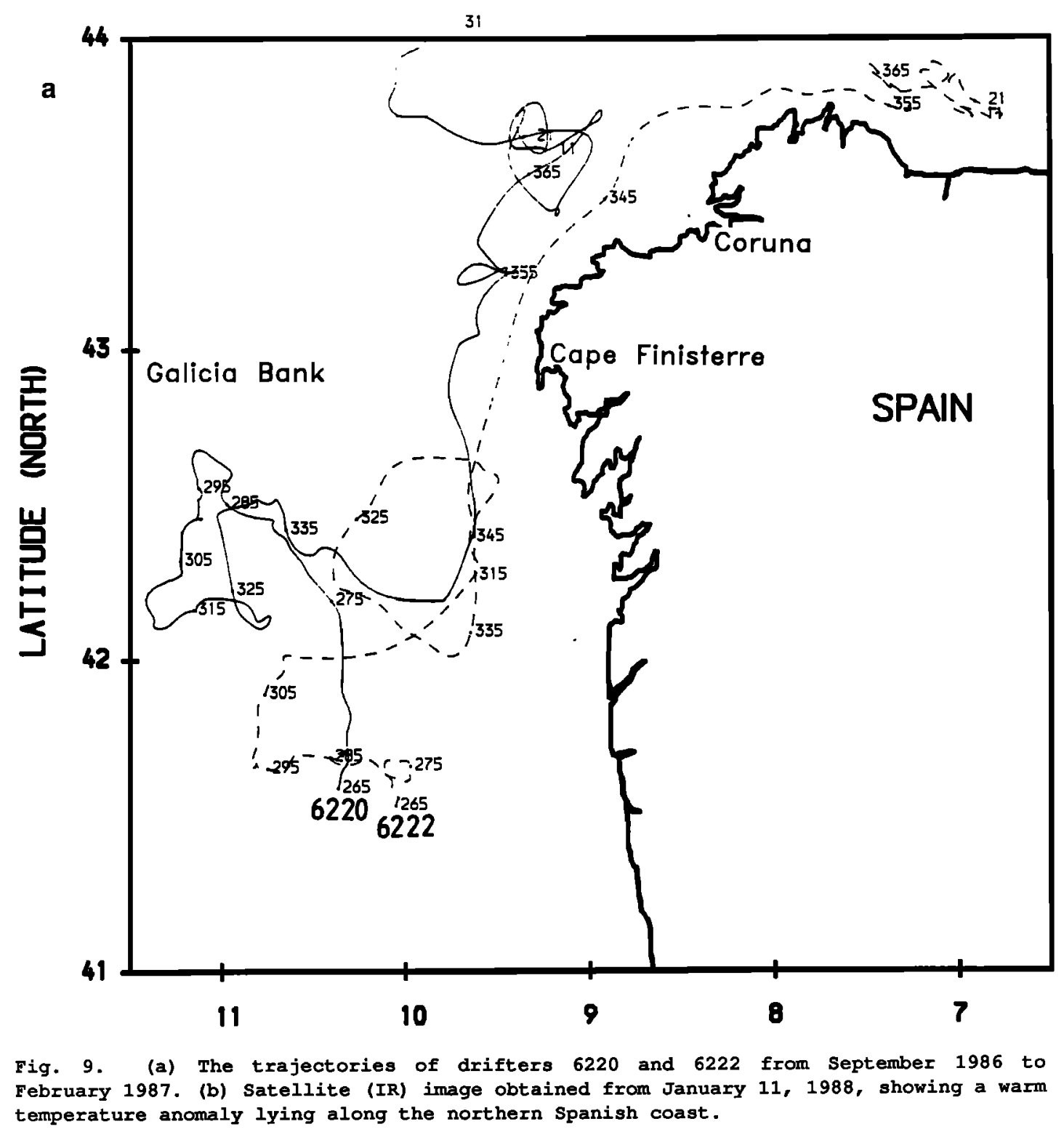

the dynamics of the California Current system using ocean models, proposed that the most likely cause of the Davidson Current was a positive wind stress curl forcing poleward Sverdrup transport. Maps produced by A. Bakun (personal communication, 1987) show that the wind stress curl off the Iberian Peninsula is positive, and so the Sverdrup mechanism is a candidate for driving the poleward current reported here.

Chelton et al. [1988] describe observations of a poleward current during spring and summer of 1981 and 1984 off central California remarkably similar to those seen off Iberia. They attribute the poleward currents to the propagation of coastally trapped waves related to wind forcing. However, because of the short length of our observations the hypothesis of forcing by coastally trapped waves cannot be examined. Huyer and Kosro [1987] observed an upwelling relaxation event off central California with characteristics comparable to those observed off Iberia. However, important differences were that the poleward flow was confined to a narrow $(<15 \mathrm{~km}$ wide) region over the continental shelf and that it persisted for only a week. They attributed the poleward flow to relaxation from upwelling when equatorward winds diminished. However, the satellite evidence from the Iberian Peningula shows that the poleward flow pergists for much longer time scales, of the order of months.

The west coast of Australia is also a subtropical eastern boundary, but even though it experiences year round equatorward winds, the coastal circulation is characterised by a narrow surface poleward flow, the Leeuwin Current [Thompson, 1984]. This intensifies as it flows poleward, despite the opposing wind, but does attain maximum strength in the austral winter when the alongshore winds are weakest. McCreary et al. [1986] attribute the Leeuwin Current to thermohaline forcing due to a meridional increase of surface density, associated with the poleward cooling of the sea surface. A consequence is that the dynamic height of the sea 
b

\section{SEA - SURFACE TEMPERATURE 11/01/88}

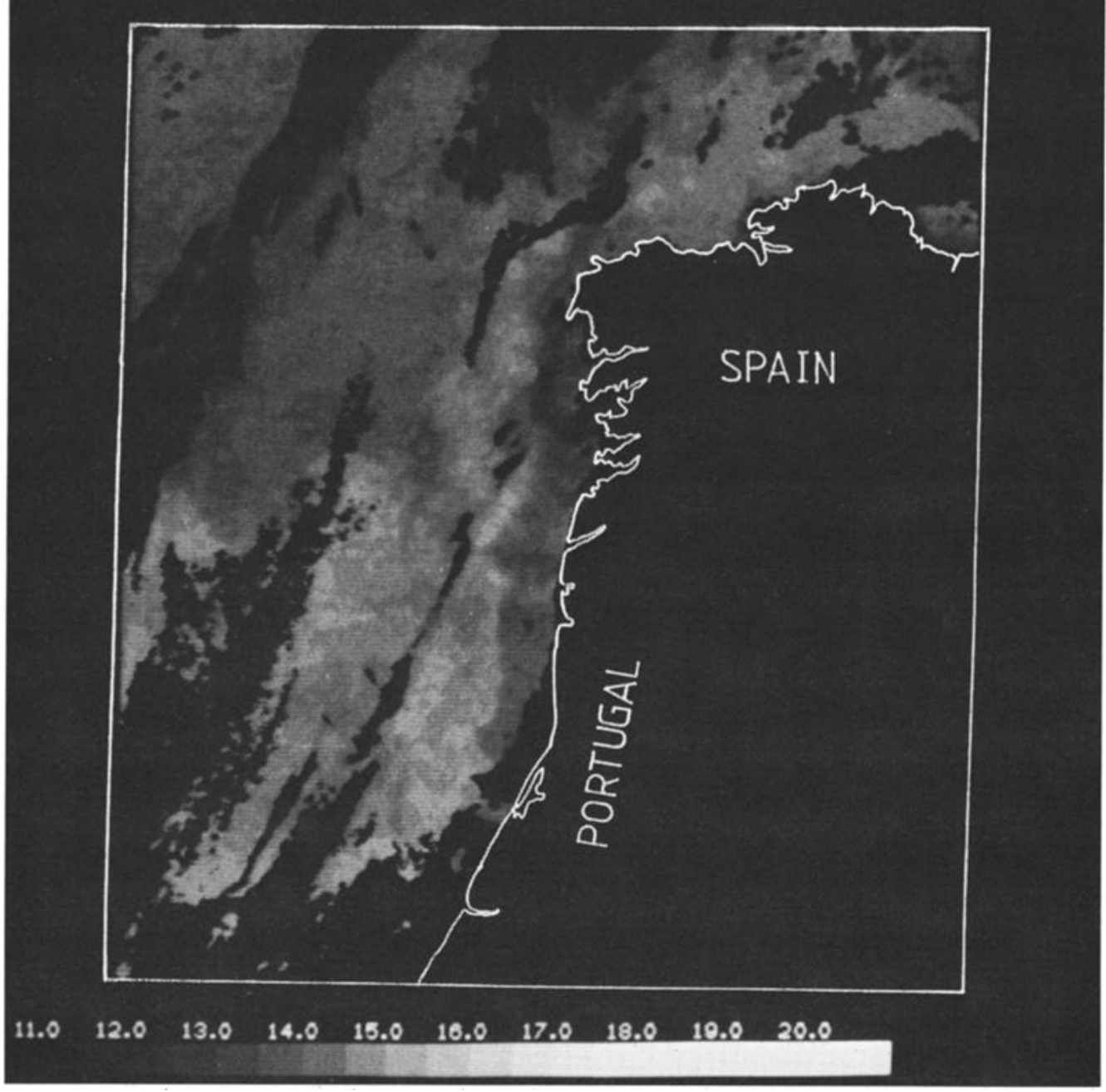

Fig. 9. (con̨tinued)

surface drops towards the poles, driving an eastward geostrophic current in the interior ocean. At an eastern ocean boundary, this interior flow forces coastal downelling and a surface poleward current. The model results of McCreary et al. [1986] showed that the speed of the alongshore currents increases poleward, reaching maximum values at the southern edge of the forcing region, as the surface current must strengthen to provide an outlet for the onshore interior flow. The austral winter maximum in the strength of the Leeuwin Current is due to the reduction of the opposing wind stress, allowing a stronger thermohaline current.

The geostrophic flow of the northeast At lantic has recently been summaxized by Pollard and $P U$ [1985]. They show that the interior geostrophic flow is directed eastwards in a broad band north of $33^{\circ} \mathrm{N}$, and so thermohaline forcing could be a possible driving mechanism for the Iberian poleward surface flow. Huthnance [1986] has proposed that thermohaline forcing is responsible for the Rockall slope Current and has collated fragmentary current observations on the European shelf margin which show slope currents north and west of Scotland, off Porcupine Bank, and on the
Celtic slope south of Goban Spur. A.t. Hill and E.G. Mitchelson-Jacob (unpublished manuscript, 1989) presented observations that suggest that the Porcupine and Scottish slope currents may be continuous.

It is tempting to postulate that the scottish, Porcupine, and Iberian slope currents may be continuous. There are numerous reports of observations of poleward flows along the continental slope of the eastern boundary throughout the North Atlantic subtropical gyre, which might suggest that there is, in some sense, continuity of poleward flow along the entire eastern boundary [Barton, 1989]. The Iberian current is suppressed during the summer months, when the equatorward winds drive an offshore Ekman transport and force upwelling at the coast. Upwelling causes the surface dynamic height to decrease towards the coast and the resulting equatorward geostrophic current is enough to counter the slope current at and near the surface. The deeper waters, however, still flow poleward, as indicated by all the observational evidence.

The Iberian slope current may be responsible for the northward advection of Mediterranean 

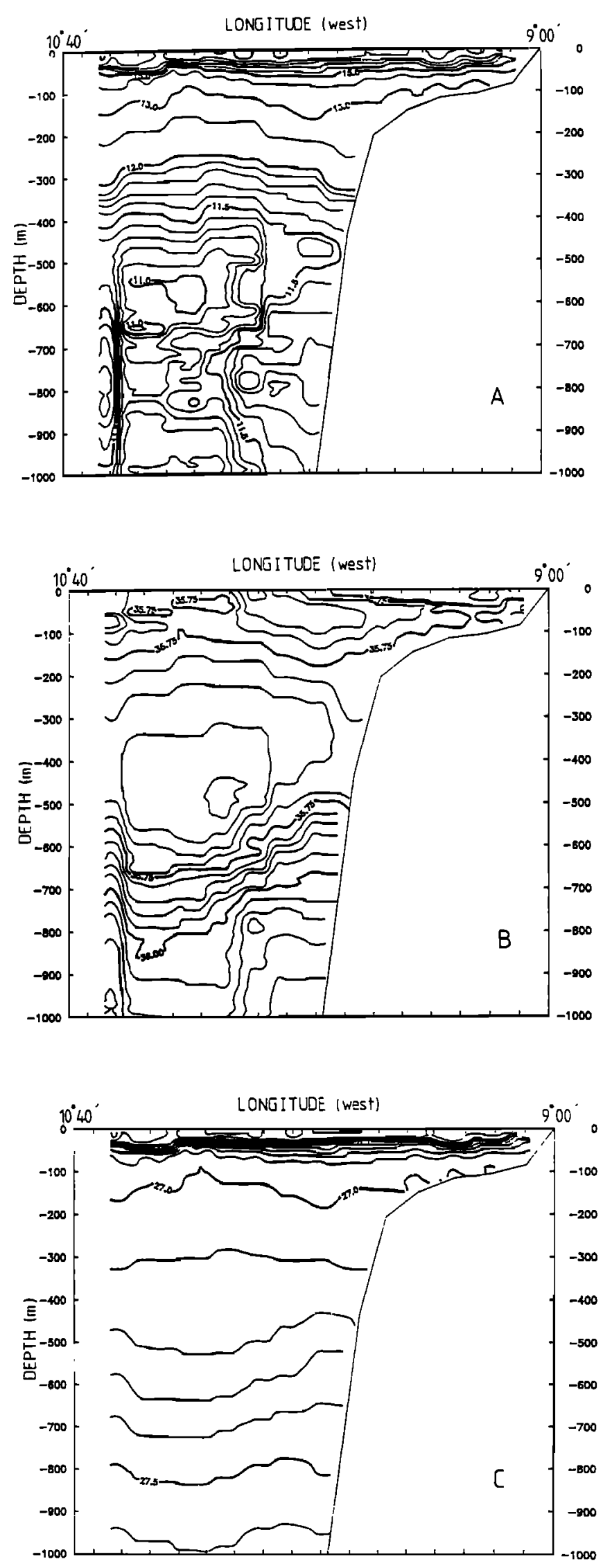

Fig. 10. Vertical sections of (a) temperature, (b) salinity, and (c) density anomaly $\sigma_{t}$ along the southern line (line $s$ ).
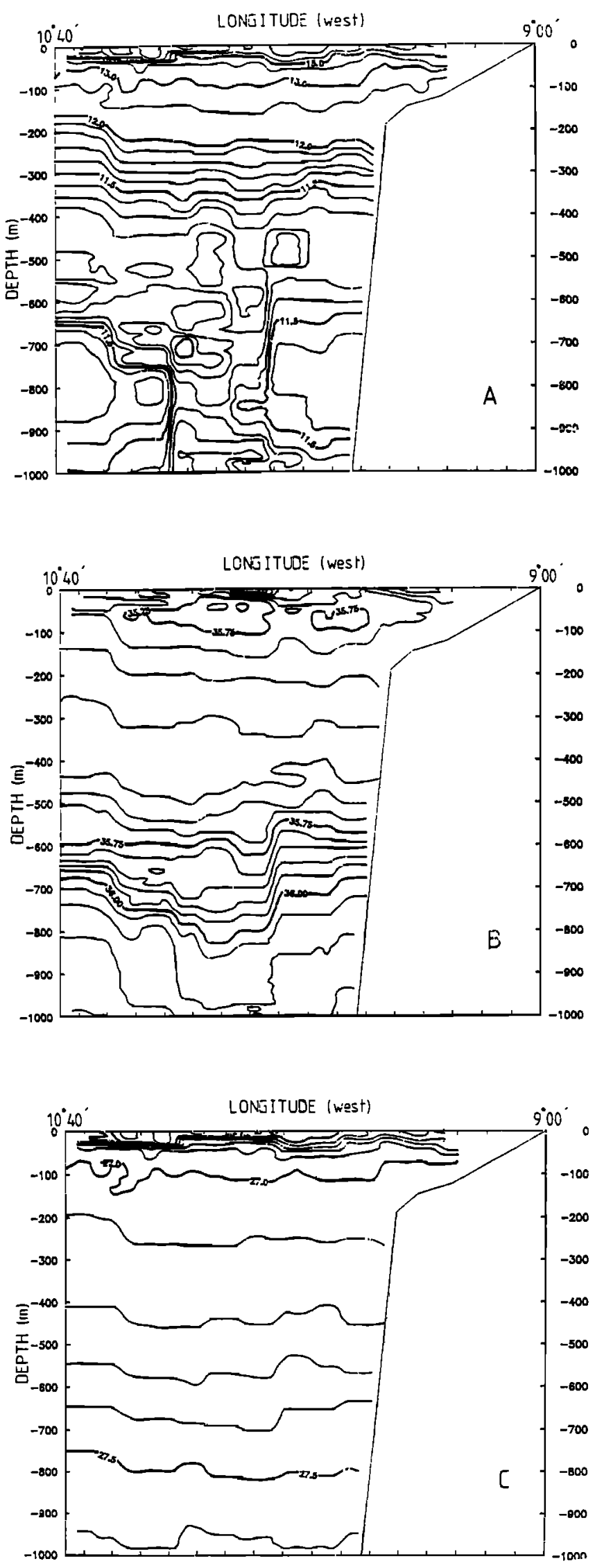

Fig. 11. Vertical sections of (a) temperature,

(b) salinity, and (c) density anomaly $\sigma_{t}$ along the northern line (line $N$ ). 

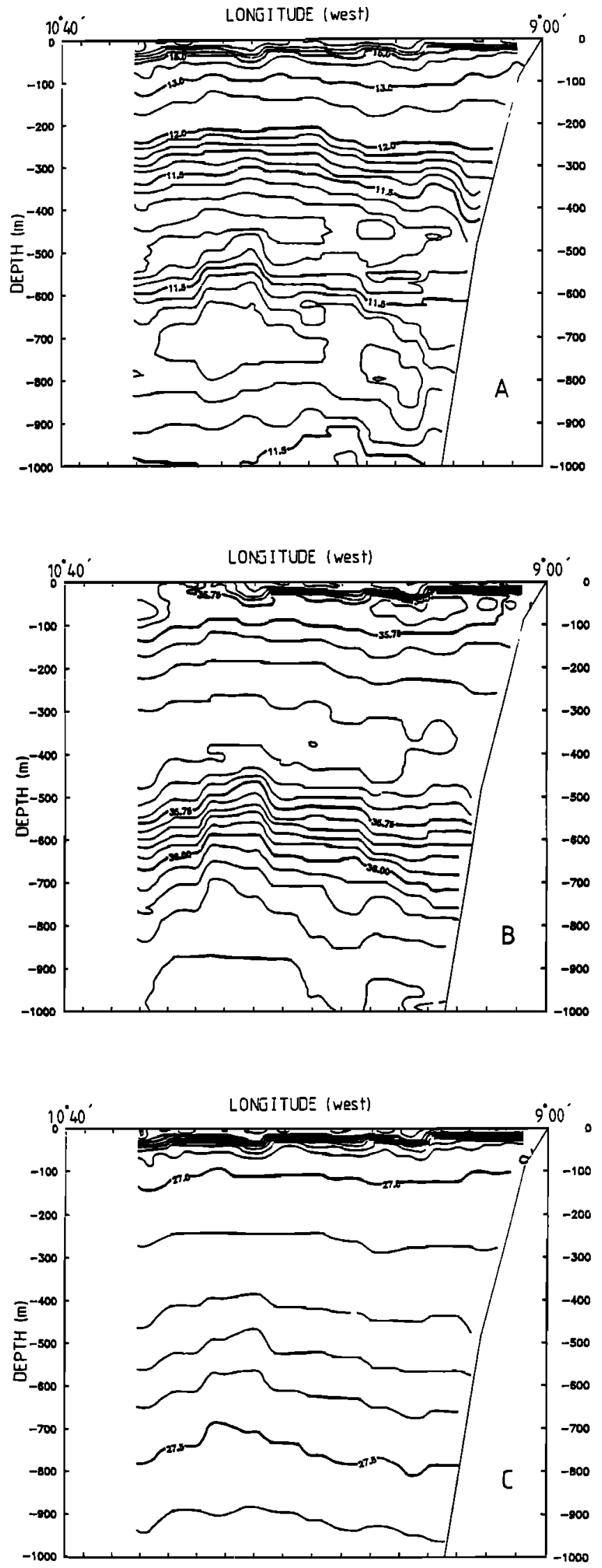

Fig. 12. Vertical sections of (a) temperature, (b) salinity, and (c) density anomaly $\sigma_{t}$ along the central line (line $c$ ).
Water ultimately into the Norwegian Sea. This idea was first proposed by Helland-Hansen and Nansen [1926], and subsequently by Reid [1979]. Our deep CTD data show that the Mediterranean Water does not flow as a simple northward flowing jet along the continental slope off the Atlantic coast of Iberia. It is characterized instead by isolated bodies of Mediterranean water indicating the presence of eddies within the flow. These observations are consistent with the results of Kalse et al. [1989], who also observed eddies in the Mediterranean water and postulated that baroclinic instabilities generated by the northward flowing undercurrent lead to the generation of meddies. There is still a lack of systematic observation along the boundary with which to investigate these ideas of continuity and eddy production in any detail.

Acknowledgments. We are grateful to the captain, officers and crew of the charter vessel $M / v$ Bon Entente, and our colleagues at JCNW for their willing cooperation at sea. We thank R. Pollard and $J$. Smithers for the loan and maintenance of Seasoar, respectively. Drifters were provided by ONR, courtesy of P. Niiler. We also thank $w$. slade and $I$. Pilling for their help in processing the AVHRR imagery. The project was funded by NERC grant GR3/5872.

\section{References}

Ambar, I.J., Seis meses de medicoes de correntes, temperaturas e salinidades na vertente continental ao largo da costa alentejana. Relat. Tec., 1/84, 47 pp., Grupo de Oceanografia, Universidade de Lisboa, Lisbon, 1984.

Ambar, I.J., Seis meses de medicoes de correntes, temperaturas e salinidades na vertente continental Portuguesa a $40 \mathrm{~N}$, Relat. Tec., 1/85, 40 pp., Grupo de Oceanografia, Universidade de Lisboa, Lisbon, 1985.

Ambar, I., A. Fiuza, T. Boyd, and R. Frouin, Observations of a warm oceanic current flowing northward along the coasts of portugal and Spain during Nov-Dec 1983. Eos Trans. AGU, $67(44), 1054,1986$.

Barton, E.D., The poleward undercurrent on the eastern boundary of the subtropical North Atlantic, in Poleward Eastern Boundary Currents, edited by S. Neshyba, C.N.K. Mooers and R.I. Smith, PP. 82-95, Springler-Verlag, New York, 1990.

Chelton, D.B., A.W. Bratkovich, R.I. Bernstein, and P.M. Kosro, Poleward flow off central California during the spring and summer of 1981 and 1984, J. Geophys. Res., 93, $10604-10620,1988$.

Fiuza, A.F.de G., The Portuguese coastal upwelling system, in Present Problems of Oceanography in Portugal, pp. 45-71, Junta Nacional de Investigacao Cientifica e Tecnologica, Lisbon, 1982.

Flament, P., I. Armi, and I. Mashburn, The evolving structure of an upwelling filament, J. Geophys.Res., 90, 11765-11778, 1985.

Helland-Hansen, B., and F. Nansen, The eastern North Atlantic. Geofys. Publ., 4, 1-76, 1926.

Huthnance, J.M., The Rockall slope current and shelf-edge processes, Proc. R. Soc. Edinburgh Sect.B, 88, 83-101, 1986. 
Huyer, A., Coastal upwelling in the California current system, Prog. Oceanogr., 12, 259-284, 1983.

Huyer, A., and P.M. Kosro, Mesoscale surveys over the shelf and slope in the upwelling region near Point Arena, California, $J$. Geophys. Res., 92, 1655-1681, 1987.

Käse, R.H., A. Beckmann, and H.H. Hinrichsen, Observational evidence of salt lens formation in the Iberian Peninsula, $I$ Geophys. Res., 94, 4905-4912, 1989.

Lacombe, H., Physical oceanography of the eastern boundary current of the Atlantic Ocean, ICSU/SCOR working party 31, The geology of the East Atlantic continental margin Rep. 70/13, edited by F.M. Delany, PP. 47-65, Institute of Geological Sciences, London, 1971.

Iynn, R.J., and J.J. Simpson, The California Current system: The seasonal variability of its physical characteristics, J. Geophys. Res., 92, 12947-12966, 1987.

Madelain, F., Etude hydrologique au large de la Peninsule Iberique, Cah. Oceanogr., 19, 125-136, 1967.

McClain, C.R., S.-Y. Chao, L.P. Atkinson, J.O. Blanton, and F. de Castillejo, Wind-driven upwelling in the vicinity of Cape Finisterre, Spain, J. Geophys. Res., 91, 8470-8486, 1986.

Mcclain, E.P., W.G. Pichel, and C.C. Walton, Comparative performance of AVHRR-based multichannel sea surface temperatures, $J$. Geophys. Res., 90, 11587-11601, 1985.

McCreary, J.P., S.R. Shetye, and P.K. Kundu, Thermohaline forcing of eastern boundary currents: With application to the circulation off the west coast of Australia, J. Mar. Res., 44, 71-92, 1986.

McCreary, J.P., P.K. Kundu, and S.-Y. Chao, on the dynamics of the California Current system, J. Mar. Res., 45, 1-32, 1987.

Niller, P.P., R.E. Davies, and H.J. White, Water following characteristics of a mixed layer drifter, Deep Sea Res., 34, 1867-1882, 1987.

Pollard, R.T., and S. Pu, Structure and circulation of the upper Atlantic Ocean northeast of the Azores, Prog. Oceanogr., 14, 443-462, 1985 .

Reid, J.L., on the contribution of the Mediterranean Sea outflow to the Norwegian-Greenland Sea, Deep Sea Res., 44, 1199-1223, 1979.

Thompson, R.O.R.Y., Observations of the Leeuwin Current off western Australia, J. Phys. Oceanogr., 14, 623-628, 1984.

wooster, W.S., and J.L. Reid, Eastern boundary currents, in the The sea, vol. 2, edited by M.N. Hill, PP. 253-280, Interscience, New York, 1963.

Wooster, w.S., A. Bakun, and D.R. McLain, The seasonal upwelling cycle along the North Atlantic, J. Mar. Res., 34, 131-141, 1976.

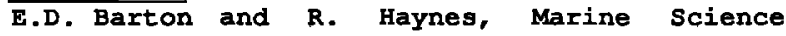
Laboratories, University College of North Wales, Menai Bridge, Gwynedd, IL59 5EY, United Kingdom.

(Received September 14, 1989; accepted October $26,1989$. 